\title{
Annual and monthly runoff analysis in the Elqui River, Chile, a semi-arid snow-glacier fed basin
}

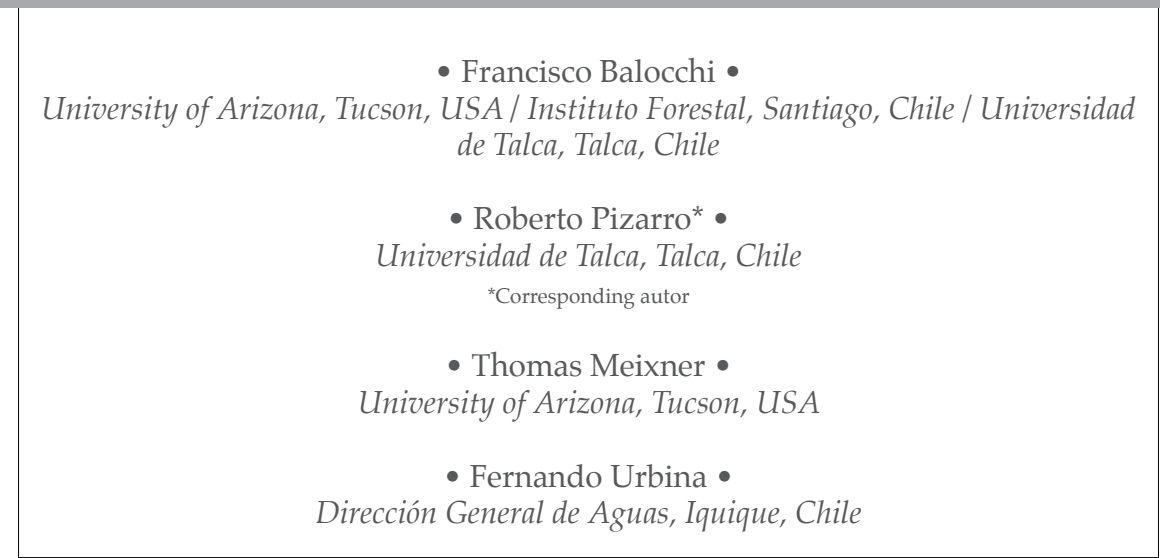

DOI: $10.24850 /$ j-tyca-2017-06-02

\begin{abstract}
Balocchi, F., Pizarro, R., Meixner, T., \& Urbina, F. (NovemberDecember, 2017). Annual and monthly runoff analysis in the Elqui River, Chile, a semi-arid snow-glacier fed basin. Water Technology and Sciences (in Spanish), 8(6), 23-35, DOI: 10.24850/j-tyca-2017-06-02.

Climate change and its relationship to temperature are critical factors affecting glaciers, especially when populations depend on these ice reservoirs. The use of the precipitationrunoff coefficient in semi-arid, mountainous regions that are fed by glaciers can lead to important findings about how glacial melt responds to climate change. This study analyzed 40 years of monthly and annual precipitation and runoff data (1970-2009) from four sub-basins of the Elqui River $\left(29^{\circ} 27^{\prime}-30^{\circ} 34^{\prime} \mathrm{S}\right.$ and $\left.71^{\circ} 22^{\prime}-69^{\circ} 52^{\prime} \mathrm{W}\right)$, in the Coquimbo region of Chile. The Elqui basin has a rainsnow-glacial melt regime. The areal average rainfall was estimated using the Thiessen polygon method. Gumbel and Goodrich probability distribution functions and the Log-Normal Probability Density Function (PDF) were used to understand the temporal behavior of precipitation and streamflow. The data-time behavior and $P P Q^{-1}$ coefficients were also analyzed. And the Mann-Kendall (MK) test was used to compare the results. No trends were found for flow, while a negative trend in rainfall was identified. The summer flows were notable, which remained constant. In spite of the differences between the $P P Q^{-1}$ coefficient and the MK test, the flow clearly does not come from rainfall but rather from glacial melt.
\end{abstract}

Keywords: Glacial melt, Mann-Kendall, precipitation and flow coefficient, glacier-fed basin, Gumbel distribution, rainfall and flow trend.
Balocchi, F., Pizarro, R., Meixner, T., \& Urbina, F. (noviembrediciembre, 2017). Análisis de la escorrentía anual y mensual en el río Elqui, Chile, una cuenca semi árida de régimen nivoglaciar. Tecnología y Ciencias del Agua, 8(6), 23-35, DOI: 10.24850/j-tyca-2017-06-02.

El cambio climático y su relación con la temperatura es un factor crítico que afecta a los glaciares, especialmente cuando la población depende de las reservas de hielo. Usando la relación precipitaciónescorrentía en regiones montañosas semiáridas alimentadas por glaciares se pueden llevar a cabo importantes descubrimientos sobre cómo el derretimiento glaciar responde al cambio climático. En este estudio se analizaron 40 años (1970-2009) de datos de precipitación y escorrentía mensual y anual en cuatro subcuencas del río Elqui $\left(29^{\circ} 27^{\prime}-30^{\circ} 34^{\prime} S\right.$ y $71^{\circ} 22^{\prime}-69^{\circ} 52^{\prime}$ O) en la región de Coquimbo, Chile. La cuenca del Elqui posee un régimen pluvionivoglaciar. La precipitación areal promedio se estimó usando el método de polígonos de Thiessen. Se utilizaron las funciones de distribución de probabilidad de Gumbel, Goodrich y Log-Normal, con el fin de entender el comportamiento temporal de ambas variables. También se analizaron la variación temporal y el coeficiente $\mathrm{PP}^{\mathrm{-}}$. El test Mann-Kendall (MK) se empleó para comparar los resultados; no se encontraron tendencias para el caudal, pero sí una tendencia negativa en las precipitaciones. Vale la pena destacar los caudales de verano, los cuales se mantuvieron constantes. A pesar de las diferencias entre el coeficiente $\mathrm{PP}^{-1}$ y el test de $M K$, es claro que el caudal no proviene de las precipitaciones sino del fenómeno de derretimiento nivoglaciar.

Palabras clave: derretimiento glacial, Mann-Kendall, coeficiente precipitación-caudal, cuenca glaciar, distribución de Gumbel, tendencias de precipitación y caudal.

Received: 01/12/2016

Accepted: 20/06/2017 


\section{Introduction}

In arid and semiarid mountain regions, the cryosphere is the principal water supply and the most vulnerable to climate change as the ice is a source of natural storage during the summer and / or dry season (Karimi, Farajzadeh, Moridnejad, \& Namdari, 2014; Milana \& Maturano, 1999; Rabatel et al., 2008). In fact, rock glaciers are essential for hydrologic sources because they have more water than glaciers that retain frozen water between $29^{\circ} \mathrm{S}$ and $32^{\circ} \mathrm{S}$ (Azócar \& Brenning, 2010). Moreover, the principal water provider to streamflow in mountainous regions is the snowmelt process (Favier, Falvey, Rabatel, Praderio, \& López, 2009). However, during a drought, glaciers and permafrost can be the main source to summer streamflow and aquifer recharge (Favier et al., 2009; Milana \& Güell, 2008).

In this context, several studies have shown glacier retreat in the previous decades (Bolch, 2007; Le Quesne, Acuña, Boninsegna, Rivera, \& Barichivich, 2009; Rivera, Acuña, Casassa, \& Bown, 2002). This phenomenon results in increasing runoff and a reduction of water infiltration. Hence, glacier melt studies are essential in water resources research (Rignot, Rivera, \& Casassa, 2003; Rivera, Casassa, Acuna, \& Lange, 2000). In fact, glacier and permafrost meltwater input to streamflow is little researched and often misunderstood (Pourrier, Jourde, Kinnard, Gascoin, \& Monnier, 2014). Even more, Rabatel, Castebrunet, Favier, Nicholson and Kinnard (2011) mentioned that models and mass balance studies, which explain runoff patterns, do not exist for sub-tropical region.

On the other hand, runoff and snowpack are highly affected by precipitation changes (Yao, Liu, Huang, Liu, \& Wu, 2014). Likewise, and in the presence of climate change, it would be expected that in the absence of changes in precipitation and with increasing temperature (Pizarro et al., 2013; Valdés-Pineda et al., 2014) runoff should have increased in the last several decades. Another factor that should affect the snowpack and glacier is the zero degree isotherm (ZDI). The ZDI is being modified by global warming (Valdes-Pineda et al., 2014), because the air is warmer. Moreover, the same study showed that the ZDI line has been rising since the 1980 's at a rate of almost $2.5 \mathrm{~m}$ every ten years, denoting a quick change in the environment. In the same context, Carrasco, Casassa and Quintana (2005), and Carrasco, Osorio and Casassa (2008) had studied the ZDI in Chile and they have concluded an increase in the ZDI in the wake of increasing temperature. Demaria, Maurer, Thrasher, Vicuña and Meza (2013) forecasted in the future with mathematical modelling that the precipitation in Chile may drop between $7-20 \%$, i.e. less snow and less streamflow.

Some studies have related hydroclimatic factors such as runoff and/or precipitation to glacier-fed river flows (Baraer et al., 2012; Birsan, Molnar, Burlando, \& Pfaundler, 2005; Kong \& Pang, 2014; Liu, Wang, Gong, \& Uygen, 2012; Pellicciotti, Bauder, \& Parola, 2010; Sharif, Archer, Fowler, \& Forsythe, 2013; Souvignet, Oyarzún, Verbist, Gaese, \& Heinrich, 2012; Jiang, Zhou, \& Cheng, 2007; Yao et al., 2014;). Moreover, these studies have a common factor in the methodology; all have used the MannKendall trend test (MK). For example, Birsan et al. (2005) analyzed 48 watersheds in Switzerland and found a positive trend in annual streamflow. Yao et al. (2014) discovered an important glacial retreat in the Yangtze River in China and that just less than $20 \%$ of rainfall was transformed into runoff in the study basin. Despite the different objectives and data used in these studies, all of them concluded that mountainous basins are one of the most sensitive places to climate change and especially sensitive are basins with glaciers. Moreover and related with the glacier response to the meteorological data, Yamaguchi and Fujita (2013) found that in general the glaciers depend mostly on the precipitation pattern such as seasonality and amount.

Souvignet et al. (2012) studied the meteorological trend in northern Chile and they found a positive trend in summer temperature at high altitudes, a related with a decrease in rainfall 
in a long-term analysis the higher temperatures could explain glacial retreat within the study zone.

Other researchers have studied the contributions of glacier melt into the streamflow, for example, Hirose and Marshall (2013) in British Columbia, Howat, Tulaczyk, Rhodes, Isreal and Snyder (2006) in California, Singh and Kumar (1997) on the Himalayas, Ye et al. (2005) in China, among others.

A severe water availability gap affects northern Chile, but Chile is considered one of the Latin American countries with the highest water volume available (DGA, 1999). According to the Valdés-Pineda et al. (2014) study, the average water availability in Chile is $53953 \mathrm{~m}^{3}$ $\mathrm{hab}^{-1} \mathrm{yr}^{-1}$ and the worldwide water availability is $6600 \mathrm{~m}^{3} \mathrm{hab}^{-1} \mathrm{yr}^{-1}$. However, from Santiago to the north of Chile, the availability is less than $800 \mathrm{~m}^{3} \mathrm{hab}^{-1} \mathrm{yr}^{-1}$, and the Coquimbo Region has $1020 \mathrm{~m}^{3} \mathrm{hab}^{-1} \mathrm{yr}^{-1}$.

The goal of the present study is to analyze, statistically and mathematically, the temporal precipitation and runoff patterns to determine if glacier retreat is affecting streamflow in the Elqui River watershed, Coquimbo Region, in Northern Chile. This hypothesis is based on the following facts: (1) glacier retreat has generated increased runoff but with little data available to confirm, (2) runoff and snowpack are highly affected by precipitation changes and, with climate change, it would be expected that in the absence of changes in precipitation and with increasing temperatures, runoff should have increased or been maintained in the last several decades, and (3) the ZDI is being modified by global warming in response to increasing temperatures.

\section{Methods}

\section{Study area}

The Coquimbo Region has $7.02 \mathrm{~km}^{2}$ of covered glacier surface and the Tapado glacier, the highlight of the Region, is located in the Elqui river's headwaters. It lies near $30^{\circ} 08^{\prime} \mathrm{S}$ and $69^{\circ} 55^{\prime} \mathrm{W}$ with an altitude of 5200 masl (meters above sea level). It has an area of $3.6 \mathrm{~km}^{2}$, which represents an important part of the entire area covered by glaciers in the region (Oyarzun, 1987; Rivera et al., 2000).

The Elqui River watershed, located in the Coquimbo Region, lies near latitudes $29^{\circ} 02^{\prime} \mathrm{S}$ and $32^{\circ} 34^{\prime} \mathrm{S}$ and longitudes $71^{\circ} 22^{\prime} \mathrm{W}$ and $69^{\circ} 52^{\prime} \mathrm{W}$ (figure 1). It has an area of $9656 \mathrm{Km}^{2}$ and has a mixed hydrologic regimen (snow and precipitation). However, according to Young et al. (2010), the principal water sources to the Elqui river streamflow are snowmelt and glacier melt. Climatically, it is in the boundary between the desert climate of northern Chile and the semiarid climate of central Chile (Cabezas, Cepeda, \& Bodini, 2007).

\section{Data acquisition}

This study is based on the monthly and annual precipitation data from four rain gauges and runoff records from 4 river gauging stations of the Elqui river watershed (figure 1 and table 1). The elevation of runoff gauging stations range between 860 masl (meters above sea level) and 3130 masl, and the elevations of rain gauges range between 1560 masl and 3130 masl. The area of the sub-basin under study ranges between $222 \mathrm{~km}^{2}$ and $3572 \mathrm{~km}^{2}$. The analysis was performed on the data recorded between 1970 and 2009. The required data was facilitated by the Chilean national water management institution (DGA, 1999), Coquimbo Region.

\section{Data analysis}

First, the precipitation and flow data presented discontinuous information across the study period 1970-2009. In those cases, it was necessary to complete the missing data from each station using simple linear regressions, multiple regressions and historic averages (Pizarro-Tapia, Cabrera-Jofre, Morales-Calderón, \& FloresVillanelo, 2011; UNESCO, 1982). However, multiple regressions did not get better results than linear regressions.

Second, the area of influence of rainfall stations was estimated using the Thiessen Polygon 


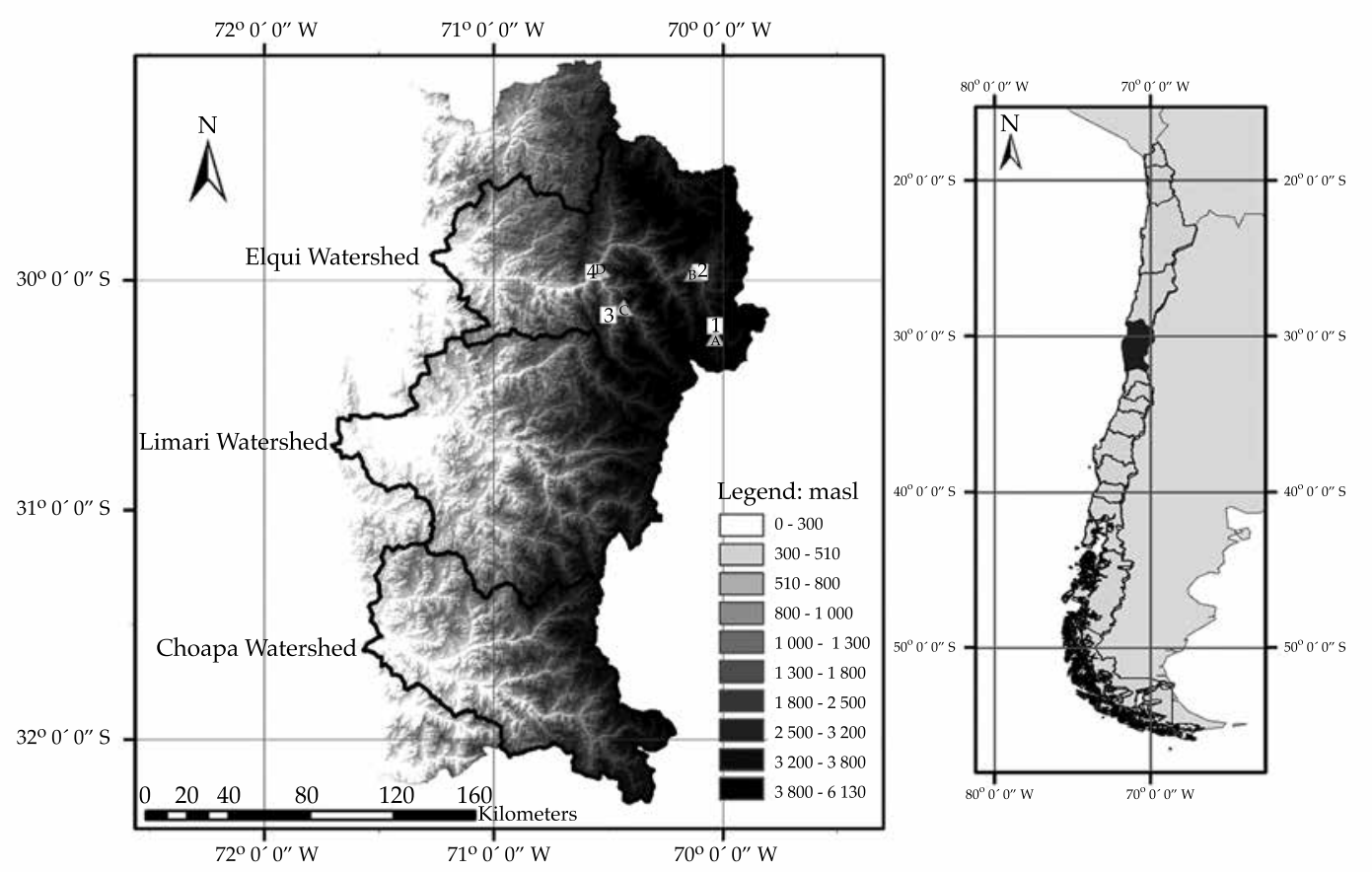

Figure 1. Elqui River watershed and gauge stations location. White squares are rain gauges and grey triangles are streamflow stations.

Table 1. Rain gauge and runoff station basic information.

\begin{tabular}{|c|c|c|c|c|c|c|}
\hline \multicolumn{7}{|c|}{ Rain Gauges } \\
\hline ID & Station & $\begin{array}{c}\text { Altitude } \\
\text { (masl) }\end{array}$ & Latitude & Longitude & \multicolumn{2}{|c|}{ Period } \\
\hline 1 & La Laguna Embalse & 3100 & $30^{\circ} 12^{\prime} \mathrm{S}$ & $70^{\circ} 02^{\prime} \mathrm{W}$ & \multicolumn{2}{|c|}{ 1970-2009 } \\
\hline 2 & Juntas & 2155 & $29^{\circ} 58^{\prime} \mathrm{S}$ & $70^{\circ} 06^{\prime} \mathrm{W}$ & \multicolumn{2}{|c|}{$1970-2009$} \\
\hline 3 & Los Nichos & 1350 & $30^{\circ} 09^{\prime} \mathrm{S}$ & $70^{\circ} 30^{\prime} \mathrm{W}$ & \multicolumn{2}{|c|}{ 1970-2009 } \\
\hline 4 & Rivadavia & 850 & $29^{\circ} 58^{\prime} \mathrm{S}$ & $70^{\circ} 34^{\prime} \mathrm{W}$ & \multicolumn{2}{|c|}{$1970-2009$} \\
\hline \multicolumn{7}{|c|}{ Runoff Stations } \\
\hline ID & Station & $\begin{array}{l}\text { Altitude } \\
\text { (m.a.s.l.) }\end{array}$ & Latitude & Longitude & $\begin{array}{l}\text { Sub-basin } \\
\text { area }\left(\mathbf{k m}^{2}\right)\end{array}$ & Period \\
\hline A & Rio la Laguna in Embalse La Laguna exit & 3130 & $30^{\circ} 12^{\prime} \mathrm{S}$ & $70^{\circ} 02^{\prime} \mathrm{W}$ & 560 & 1970-2009 \\
\hline $\mathrm{B}$ & Rio Toro before Junta Rio La Laguna & 2150 & $29^{\circ} 58^{\prime} \mathrm{S}$ & $70^{\circ} 06^{\prime} \mathrm{W}$ & 468 & 1970-2009 \\
\hline $\mathrm{C}$ & Rio Cochiguaz in El Peñon & 1360 & $30^{\circ} 07^{\prime} \mathrm{S}$ & $70^{\circ} 26^{\prime} \mathrm{W}$ & 673 & 1970-2009 \\
\hline $\mathrm{D}$ & Rio Turbio in Varillar & 860 & $29^{\circ} 57^{\prime} \mathrm{S}$ & $70^{\circ} 32^{\prime} \mathrm{W}$ & 4148 & 1970-2009 \\
\hline
\end{tabular}

method which representatively weights the rainfall depending on the surface (Pizarro-Tapia et al., 2011; Yao et al., 2014; Wada, Chikita, Kim, $\&$ Kudo, 2011). For this processing procedure, the digital topographic data of the study area was used.

Rainfall and flow data were grouped into four periods (1970-1980, 1970-1990, 1970-2000, 
and 1970-2009) to observe trends in the data over time by making an intercessional comparison and for the adjustment of the Probability Density Functions (PDFs) used. Then, 20, 50, and 75 year return periods were used to calculate the probability of exceedance for each PDF.

In this study Gumbel $\left(F(X)=P[\varepsilon \leq X]=e^{-e^{-i(X-1)}}\right)$, Goodrich $\left(F(X)=P[\varepsilon \leq X]=1-e^{-a\left(X-X_{1}\right)\left(\frac{1}{p}\right)}\right)$, and Lognormal $\left(F(X)=P[\varepsilon \leq X]=\frac{1}{X \sqrt{2 \pi \sigma^{2}}} e^{\frac{-(\ln X-\mu)^{2}}{\sqrt{2 \pi \sigma^{2}}}}\right)$ PDF's were used which are most commonly used in rainfall and flow statistical analysis. As a way to test the quality of adjustment shown by a PDF, Kolmogorov-Smirnov and Nash-Sutcliffe goodness of fit tests were used. Kolmogorov Smirnov goodness of fit test compares the deviation of the observed cumulative frequency $F n(X)$ $i$ to the theoretical cumulative frequency $F(X)$ $i$, Likewise, Nash-Sutcliffe goodness of fit test shows what proportion of the total variation in the data is represented by the model. As the PDF fit wasn't successful, we complemented the analysis of hydrological variables using the relationship between rainfall and flows where $P P Q^{-1}$ is the coefficient that indicates how many times the rainfall magnitude exceeds the flow magnitude.

To contrast these above results it was necessary to use a strong statistical test to probe the hypothesis that links precipitation and runoff patterns to possible glacier retreat. In this context, the idea to find a trend in the precipitation and discharge data is essential. Hence, one of the most widely used tools to detect trends in the data is the Mann-Kendall test (MK) (Hamed, 2008; Kendall, 1948; Mann, 1945; Song, Jiang, Lei, Wang, \& Shu, 2015). This nonparametric test has been used by a larger number of researcher from multiple fields such as hydrology, geochemistry, human behavior, ecology, medicine among others. Thus, trend test assesses whether a time-ordered dataset exhibits an increasing or decreasing trend, within a predetermined level of significance. The null hypothesis of the MK trend test is $H_{0}=\tau=0$ and the alternative hypothesis is $H_{1}=\tau \neq 0$. According to this, the MK will be used over annual and monthly (seasonal) data (areal precipitation and specific discharge) to verify if the thawing of the permafrost is responsible for the increasing or maintaining summer flows and inferred disconnections of precipitation and flow.

\section{Results and discussion}

We have analyzed each sub-basin individually on a monthly and annual basis. However and because PDF fitting was not possible, an overall overview of the data at each basin on an annual basis was performed

\section{Mean areal rainfall}

Using Thiessen polygons method, the area of influence of each rainfall station was associated with the sub-basins defined by the gaging stations in Rio Turbio en Varillar henceforth Rio Turbio; Rio Cochiguaz en El Peñon, henceforth Rio Cochiguaz; Rio la Laguna on departure Embalse La Laguna, henceforth Rio La Laguna; Rio Toro, formerly Junta Rio; La Laguna, henceforth Rio Toro (table 2). The mean areal rainfall for the sub-basins in the study was determined by weighted averages of the surfaces.

\section{PDF fitting for monthly/annual flows and rainfall}

The Gumbel (EV1) function does not fit the four sub-periods of study and for this reason, LogNormal, Pearson III, and Goodrich functions were used to fit the data. The following results do not consider Pearson III because it did not provide better results. For a return period of 50 years, Rio Turbio and Rio Cochiguaz for all the periods Log-Normal PDF was used; for Rio La and Rio Toro for the four period analyzed, a Goodrich PDF was used.

\section{Rainfall fit}

The variability of precipitation data did not permit adjustment periods as was the case for flow 
Table 2. Surfaces defined by the method of Thiessen polygons for each sub-basin.

\begin{tabular}{c|r|c|c|c}
\hline Sub-basin & Rio Turbio & Rio Cochiguaz & Rio La Laguna & Rio Toro \\
\hline Rain gauge station & \multicolumn{3}{|c|}{ Surface $\mathbf{( k m}^{\mathbf{2}}$} \\
\hline Rivadavia & 1290.6959 & - & - & - \\
\hline Los Nichos & 37.7941 & 361.0911 & - & - \\
\hline La Laguna Embalse & 631.3946 & 197.7601 & 221.8748 & - \\
\hline Juntas & 1611.7806 & - & - & 615.7333 \\
\hline Total Basin surface & 3671.6652 & 558.8512 & 221.8748 & 615.7333 \\
\hline
\end{tabular}

data fit; therefore, the adjustment was made monthly, with probability distribution functions of Gumbel, Log-Normal, and Goodrich. However, there were months where the PDF could not adjust. As a result the PDF that was used for a return period $T=50$ years.

To interpret the behavior of rainfall and flows in the recent decades and because the PDF fit was not possible at this time, on figure 2 the temporal variation and susceptibility data is represented by a trend line with the corresponding equation from both variables on an annual basis for the whole period 1970-2009.

In the case of the Rio Turbio and Rio Toro sub-basin, there is more rainfall than flow, a logical situation if hypothesized that flows originate from precipitation. Furthermore, trends in both variables are presented as a relatively stable pattern. Also, there is greater variability in the precipitation than the streamflow in both sub-basins; this can be ratified by calculating the coefficient of variation $(\mathrm{CV})$ of both variables. For precipitation at Rio Turbio sub-basin, the CV is $71.20 \%$ and $62.32 \%$ for streamflow and at Rio Toro sub-basin the precipitation's CV is $75.53 \%$ and $37.25 \%$ for the flow.

For the Rio Cochiguaz sub-basin, there is no difference between the precipitation and the flow. It is clear that in this sub-basin the flow has a slightly decreasing trend; meanwhile the precipitation shows the contrary. At Rio La Laguna sub-basin, precipitation amount does not exceed the flow which also has a decreasing trend. This decrease could be due to low water reserves in the form of ice and snow in the basin. Also, there is greater variability in precipitation than inflow, which can be verified by calculating the coefficient of variation (CV) of both variables. The precipitation's CV is $67.49 \%$ and the flow's CV is $51.23 \%$.

\section{PP $\mathrm{Q}^{-1}$ coefficient: annual analysis}

Figure 3 shows variability through the years of study where annual rainfall generally exceeds flows. However, there are moments in which this pattern is not true, $P P Q^{-1}$ is less than 1 and flow exceeds precipitation. This result could be due to the lack of stations in the upper area of the basins, which would enable them to make a better estimate of the contributions of precipitation in liquid or solid form. The Rio La Laguna sub-basin in general has annual flows that exceed precipitation, but there are years where this does not occur. The year 2000-2001 in particular draws attention as it reaches a value of 2.6 on $P P Q^{-1}$ coefficient, product of very low annual flow in that year. If this data is removed from the graph, the ratio would have a negative trend like the previous sub-basins. Despite this particular behavior for the 2000-2001 period, this sub-basin is one of the most important within the rest analyzed because the Tapado Glacier is located in the headwater.

What is clear is that the $P P Q^{-1}$ ratio tends to decrease which may be caused by two reasons. First, precipitation has decreased and flows have remained constant or on the other hand, precipitations have been steady and flows have increased. In both cases, there is speculation that there are contributions from glacier melt. Thus, on an annual basis it can be seen that the runoff is the same or it has increased despite decreasing precipitation. 
a)

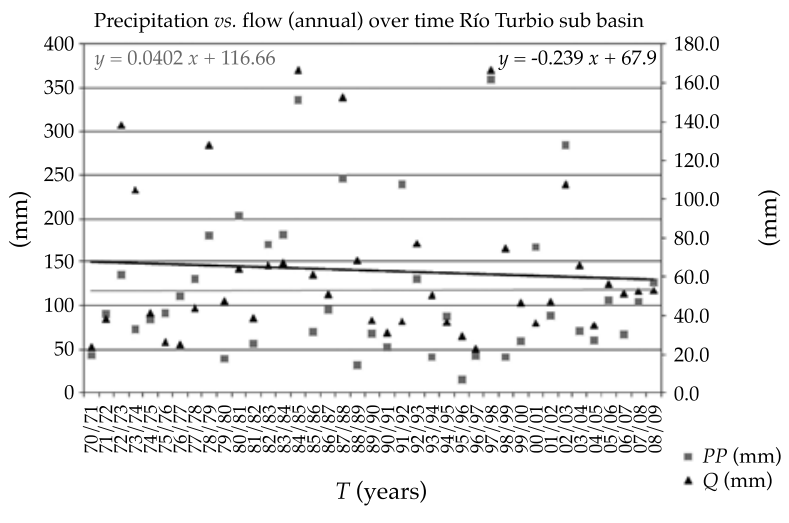

c)

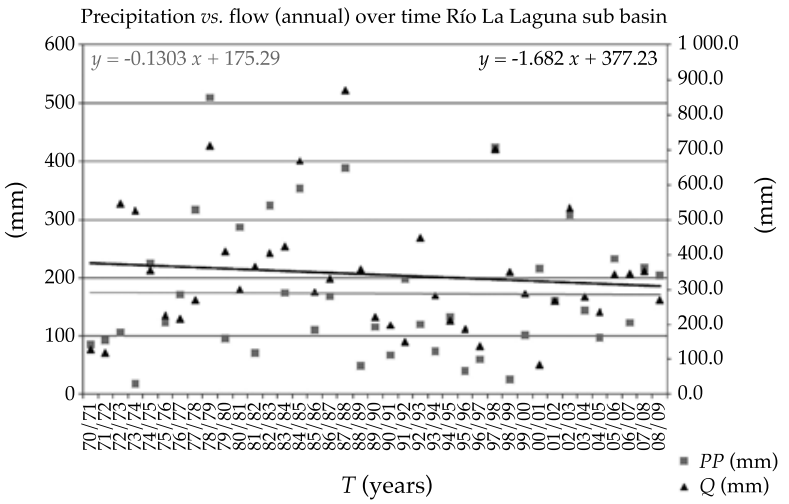

b)

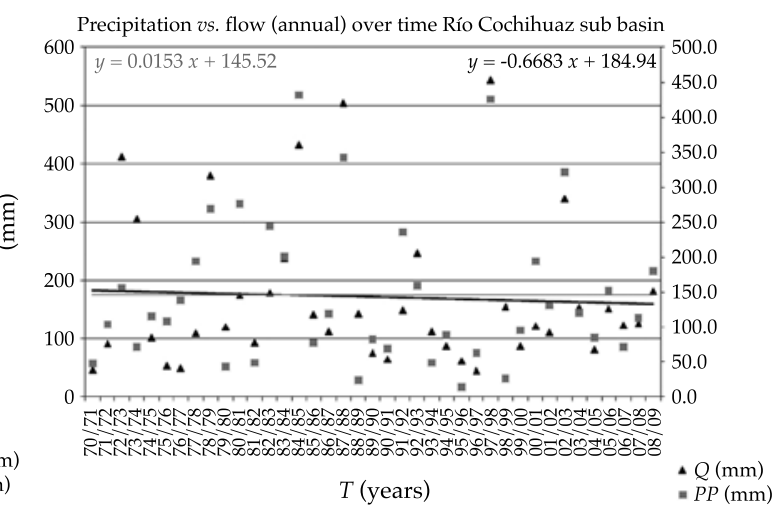

d)

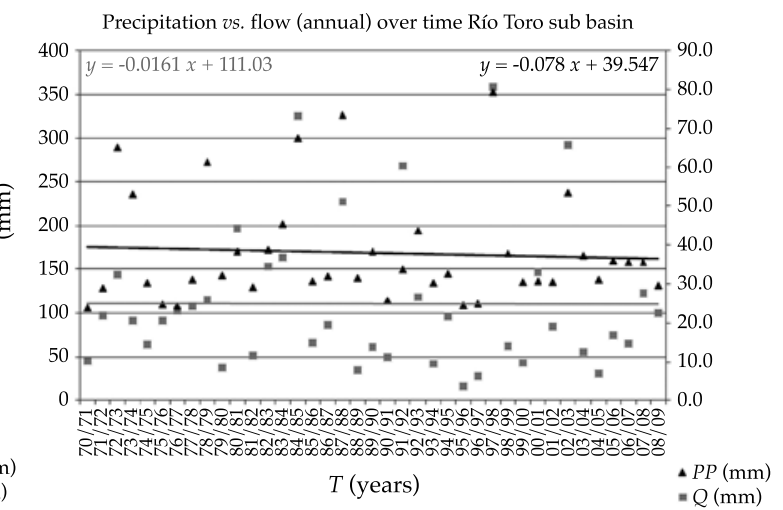

Figure 2. Annual amount $(\mathrm{mm})$ for precipitation (grey squares) vs. flow (black triangles), on the four sub-basins analyzed were: a) Rio Turbio, b) Rio Cochihuaz, c) Rio La Laguna, and d) Rio Toro.

In the 1995-1996 hydrological year, the $P P$ $Q^{-1}$ coefficient was less than 1 in the four subbasins and flows are generally in proportion to the rainfall. This situation means that it is facing a year of drought where glaciers may be supplying significant water to the stream. This situation was repeated in the years 1973-1974, 1979-1980, 1988-1989, 1993-1994, 1995-1996, and 1998-1999 in Rio Turbio, Rio Cochiguaz, and Rio La Laguna River sub-basins. However and again, Rio La Laguna has special importance due to the presence of the Tapado Glacier.

\section{PP $\mathrm{Q}^{-1}$ coefficient: summer versus winter}

Mean areal precipitation and average flow for monthly-level data are presented (table 3) to summarize if rainfall exceeded the flow or not.
The slopes represent the tendency of the precipitation or flow to decrease or increase over time. Thus, if the precipitation/flow slope is greater than zero that means that it has a positive trend in time. Otherwise, the trend is negative.

First, it can be seen that the flows are greater than the rainfall values in the spring/summer months, that is, between October and February flows were not produced from rainfall. On an annual basis, it is seen that the flow rates tend to decrease more strongly than the rainfall in all sub-basins. However, in the Rio Turbio and Rio Cochiguaz sub-basins, annual precipitations show a slight increasing trend. This trend in both Rio Turbio and Rio Cochiguaz, the highest sub-basin analyzed, might be due to the rise of the ZDI line where it has modified precipitation behavior (i.e. What was once snow is now rain). 


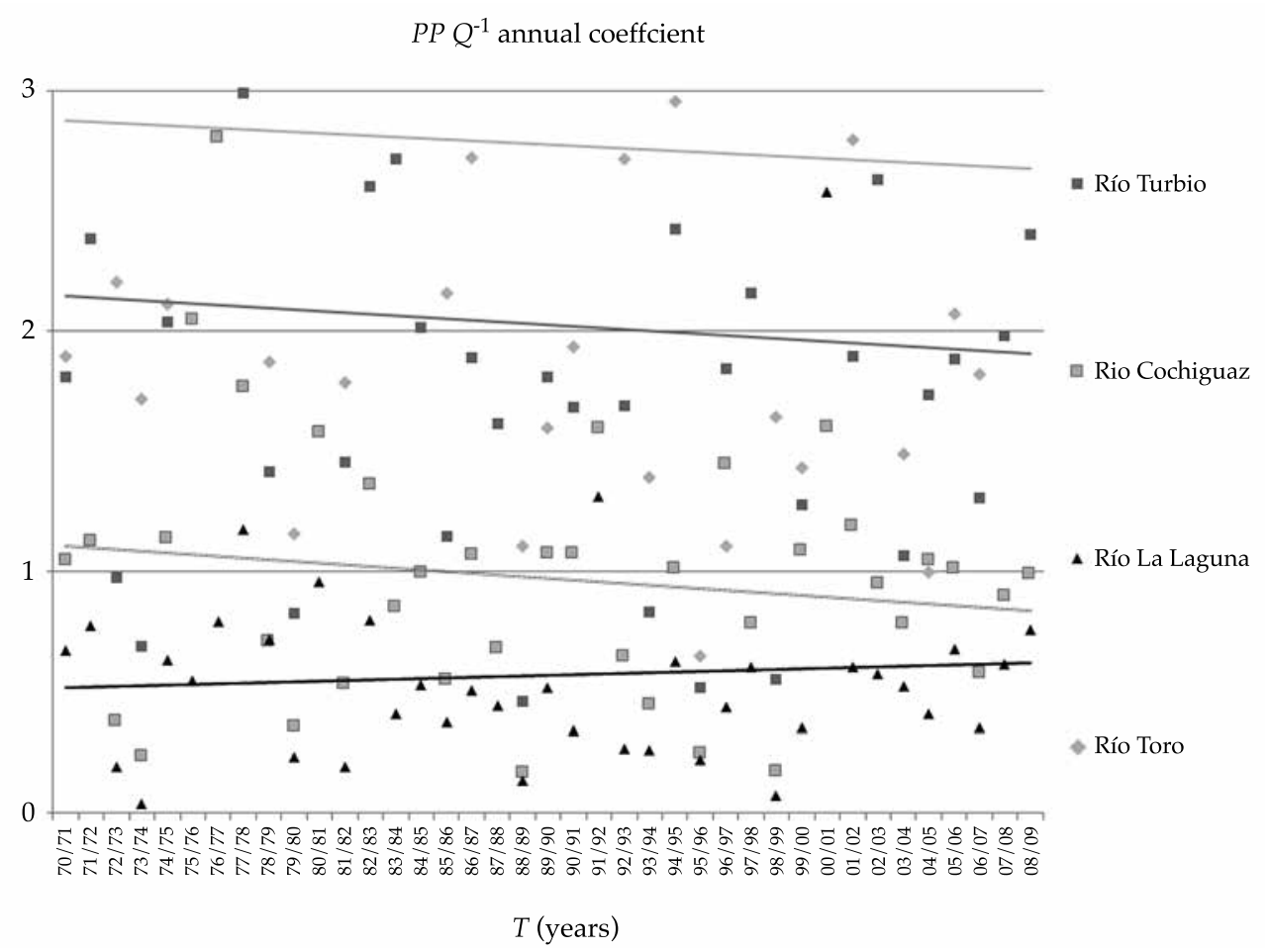

Figure 3. Graph of behavior of the $P P Q^{-1}$ ratio yearly in the Rio Turbio, Rio Cochiguaz, Rio La Laguna, and Rio Toro sub-basins.

Flows exceed precipitation values in summer months. Some proportion of this behavior could be explained by melt processes (late September and early October). However, from December to February, the snowmelt flows were still proportionally greater than the precipitation.

Furthermore, the precipitation data does not explain the flow pattern solely. It is shown that the precipitation in all sub-basins tend to decline whereas flow tends to increase or remain constant. It seemed to be that the water supply comes from snow or ice melt, since it is clear the precipitation is not feeding streamflow at least in summer time.

By the high variability of the $P P Q^{-1}$ coefficient value, a trend analysis for two summer months and two winter months was performed. First, the summer months (figure 4) have very few occasions where the values of the $P P Q^{-1}$ ratio exceed 1 which infers that rainfall rarely exceeded the value of flows. For summer drought months it is also important to highlight the trend in the months of low water for the $P P Q^{-1}$ ratio, which is mostly negative over time, which would indicate that the flows have tended to grow more than precipitation and can be attributed to a change in temperatures and a higher incidence of glacier melt and snowmelt.

Precipitation behavior does not match with the flow pattern. The $P P Q^{-1}$ coefficient for the wet months generally exceeds 1 which means that precipitation was greater than flow. There are also values that did not surpass the value 1 which were associated with dry years. In general terms, there are differences between the behavior of the summer months and the winter months since the summer months seem to express themselves with less-than-normal rainfall, which would accelerate the snow and glacial melting processes that fill the water deficit in the sub-basins in the study. 
Balocchi et al., Annual and monthly runoff analysis in the Elqui River, Chile, a semi-arid snow-glacier fed basin

Table 3. Slope of the trend line for precipitation $(m P P)$, flows $(m Q)$, and $P P Q^{-1}$ trend.

\begin{tabular}{|c|c|c|c|c|c|c|c|c|c|c|c|c|}
\hline \multirow{3}{*}{ Month } & \multicolumn{12}{|c|}{ Sub-basin } \\
\hline & \multicolumn{3}{|c|}{ Rio Turbio } & \multicolumn{3}{|c|}{ Rio Cochiguaz } & \multicolumn{3}{|c|}{ Rio La Laguna } & \multicolumn{3}{|c|}{ Rio Toro } \\
\hline & $m P P$ & $m Q$ & $\begin{array}{l}P P Q^{-1} \\
\text { Trend }\end{array}$ & $m P P$ & $m Q$ & $\begin{array}{l}P P Q^{-1} \\
\text { Trend }\end{array}$ & $m P P$ & $m Q$ & $\begin{array}{l}P P Q^{-1} \\
\text { Trend }\end{array}$ & $m P P$ & $m Q$ & $\begin{array}{c}P P Q^{-1} \\
\text { Trend }\end{array}$ \\
\hline Apr & -0.061 & -0.006 & $P P>Q$ & -0.057 & -0.056 & $P P<Q$ & 0.010 & -0.064 & $P P<Q$ & -0.139 & -0.004 & $P P>Q$ \\
\hline May & 0.216 & -0.004 & $P P>Q$ & 0.342 & 0.005 & $P P>Q$ & 0.213 & 0.041 & $P P>Q$ & 0.231 & 0.003 & $P P>Q$ \\
\hline Jun & 0.279 & -0.002 & $P P>Q$ & 0.266 & 0.049 & $P P>Q$ & 0.015 & 0.068 & $P P>Q$ & 0.411 & 0.005 & $P P>Q$ \\
\hline Jul & -0.298 & -0.007 & $P P>Q$ & -0.718 & 0.051 & $P P>Q$ & -0.635 & 0.060 & $P P>Q$ & -0.050 & 0.004 & $P P>Q$ \\
\hline Aug & 0.171 & 0.002 & $P P>Q$ & 0.309 & 0.055 & $P P>Q$ & 0.437 & 0.109 & $P P>Q$ & -0.039 & 0.005 & $P P>Q$ \\
\hline Sep & -0.030 & -0.002 & $P P>Q$ & -0.007 & 0.066 & $P P<Q$ & -0.011 & -0.284 & $P P<Q$ & -0.030 & 0.006 & $P P>Q$ \\
\hline Oct & -0.114 & -0.031 & $P P<Q$ & -0.113 & 0.012 & $P P<Q$ & -0.187 & -0.453 & $P P<Q$ & -0.126 & 0.009 & $P P<Q$ \\
\hline Nov & -0.026 & -0.026 & $P P<Q$ & 0.010 & 0.027 & $P P<Q$ & 0.056 & -0.233 & $P P<Q$ & -0.066 & 0.009 & $P P<Q$ \\
\hline Dec & -0.027 & -0.020 & $P P<Q$ & 0.007 & -0.053 & $P P<Q$ & 0.022 & -0.192 & $P P<Q$ & -0.070 & -0.021 & $P P<Q$ \\
\hline Jan & -0.046 & -0.023 & $P P<Q$ & -0.018 & -0.225 & $P P<Q$ & -0.030 & -0.187 & $P P<Q$ & -0.088 & 0.019 & $P P<Q$ \\
\hline Feb & -0.026 & -0.054 & $P P<Q$ & -0.016 & -0.303 & $P P<Q$ & -0.040 & -0.166 & $P P<Q$ & -0.029 & -0.037 & $P P<Q$ \\
\hline Mar & 0.002 & -0.006 & $P P<Q$ & 0.011 & -0.277 & $P P<Q$ & 0.021 & -0.378 & $P P<Q$ & -0.023 & -0.034 & $P P>Q$ \\
\hline Total & 0.040 & -0.239 & $P P>Q$ & 0.015 & -0.668 & $P P<Q$ & -0.130 & -1.682 & $P P<Q$ & -0.016 & -0.078 & $P P>Q$ \\
\hline
\end{tabular}

a)

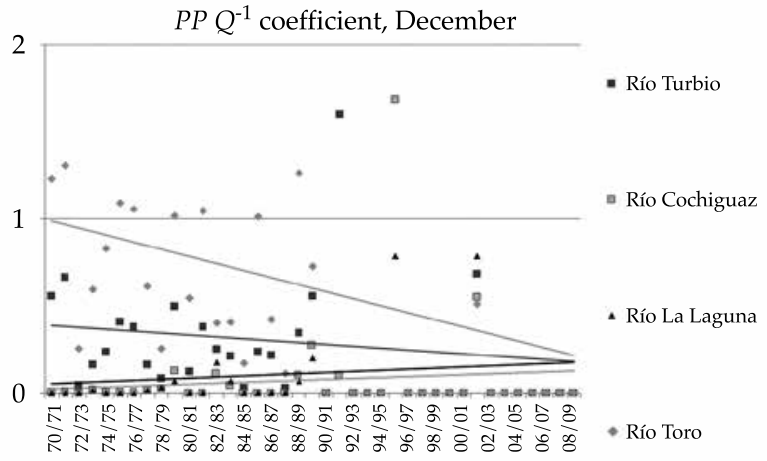

$T$ (years) b)

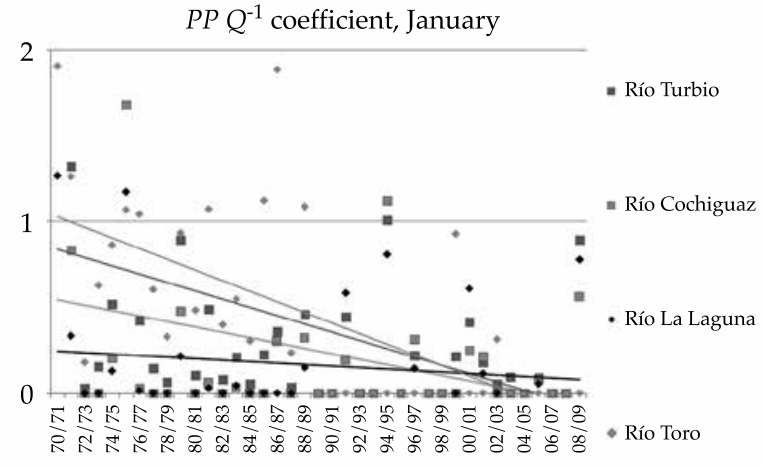

$T$ (years)

Figure 4. Graphic of the behavior of the $P P Q^{-1}$ coefficient for December (a) and January (b) in the Rio Turbio, Rio Cochiguaz, Rio La Laguna and Rio Toro sub-basins.

\section{MK trend test}

The MK test did not find significant changes in the streamflow amount, but a negative trend was found in precipitation during the dry season (summer). These results were performed using the areal precipitations and average flow (specific) annually and monthly between 1970 and 2009 in the four sub-basins studied. On table 4 , a negative sign in front of the bracket means a decreasing trend and a positive sign means an increasing trend in both discharge and precipitation.

In each of the four sub-basins, the 1970-1980 period does not present a trend in the flow data. This pattern could be possibly caused by the 
Table 4 . MK monthly trend test summary, 4 period, 4 sub-basins.

\begin{tabular}{c|l|c|c|c|c}
\hline \multicolumn{2}{c|}{} & $\mathbf{1 9 7 0 - 2 0 0 9}$ & $\mathbf{1 9 7 0 - 2 0 0 0}$ & $\mathbf{1 9 7 0 - 1 9 9 0}$ & $\mathbf{1 9 7 0 - 1 9 8 0}$ \\
\hline \multirow{3}{*}{ Rio Turbio } & $Q$ Trend & No Trend & No Trend & No Trend & No Trend \\
\cline { 2 - 6 } & $P P$ Trend & $-[$ Sep-Feb] & -[Oct-Feb] & -[Nov/Jan] & -[Jun] \\
\hline \multirow{3}{*}{ Rio Cochiguaz } & $Q$ Trend & $+[J u n]$ & No Trend & No Trend & No Trend \\
\cline { 2 - 6 } & $P P$ Trend & -[Oct-Dec] & -[Oct-Nov] & -[Jun/Nov/Jan] & No Trend \\
\hline \multirow{2}{*}{ Rio La Laguna } & $Q$ Trend & No Trend & No Trend & + +[Jun] & No Trend \\
\cline { 2 - 6 } & $P P$ Trend & No Trend & No Trend & No Trend & $+[$ Jul/Oct] \\
\hline \multirow{2}{*}{ Rio Toro } & $Q$ Trend & No Trend & No Trend & No Trend & No Trend \\
\cline { 2 - 6 } & $P P$ Trend & -[Apr/Sep-Mar] & -[Apr/Sep-Feb] & -[Apr/Jun/Sep-Mar] & -[Jan] \\
\hline
\end{tabular}

temperatures that were constant or rising in time or the effect of the rise of the ZDI is not evidenced yet.

On an annual basis, Rio La Laguna sub-basin in the 1970-1980 period (not showed) shown a positive precipitation trend. Nevertheless, this sub-basin does not have many changes in flow / precipitation.

For the Rio Turbio and Rio Cochiguaz sub-basins, the average flow does not present any trend in the four periods analyzed both annually and monthly. On the other side, precipitation shows a specific pattern, especially in the summertime where negatives trends in the precipitation pattern was found. Contrasting this and according by Favier et al. (2009), fact, Monnier, Kinnard, Surazakov and Bossy (2014) have found an important retreat of the
Tapado Glacier between 1956 and 2010 with a retreat distance closer to 400 meters. Also, at this elevation and in the winter months, the measured water in the rain gauge could be melted snow, and measurement error at this station could be an issue.

Similar relationships occur in the Rio Toro sub-basin (table 4) where no trend in flow was found. The longer periods (except in October) are the ones with the largest decreases in monthly flow. It is important to mention that this subbasin comes from the Rio La Laguna sub-basin. Because the Rio La Laguna sub-basin does not present any trend, it is highly probable that the Rio La Laguna sub-basin directly influences the flow behavior of the Rio Toro sub-basin.

Another reason that supports the fact that the rivers are fed with water from melting snow and ice, is the Valdes-Pineda et al. (2014) study, who found strong evidence of the decline of the water table in the region of Coquimbo.

A simple tendency analysis over the average temperatures (1974-2009) in Rio La Laguna station show for the annual analysis and for the winter months especially on June, July and August that the temperatures are increasing. The same analysis was performed using a seasonal MK test which found the same behavior and these results match with the findings made it by Souvignet et al. (2012).

\section{Comments and conclusions}

The $P P Q^{-1}$ ratio manifested high variability in

all the sub-basins in this analysis, but it also 
manifests a clear declining trend in the months of dry season due to flows exceeding precipitation. The flows have been maintained even though precipitation decline shave been observed. These conditions indicate that contributions from a glacier retreat are the best explanation for observed streamflow. This result matches with the Souvignet et al. (2012) study which found similar results correlated with a negative trend in precipitation and a no trend in the discharge, which could be explained by a glacial retreat too. For instance, Vicuña, Garreaud and McPhee (2011) modeling future scenarios for the Limari watershed, the closest neighbor of Elqui watershed, showed increased temperatures and decreased precipitation, which will affect direct the hydrological behavior of the watershed and especially the permafrost and snow present at high altitudes.

For each winter month there is a clear increase of rainfall, exceeding the flows, while in the dry months is evidence of maintenance of the flows related to the decline in rainfall, which would only be attributed to a greater snow/ice melt. In this same track, Favier et al. (2009) found the same relation between flow and precipitation, concluding that snow/ice melting strongly influence the water supply.

It is clear through the MK tests that streamflow in the 4 sub-basins have not undergone significant changes in their amounts. It is also clear that a negative trend in rainfall during dry periods (summer time) would explain where the water comes to maintain the flow in each of the sub-basins studied. In this context and for the known effect of climate change in Chile (Demaria et al., 2013; Pellicciotti, Ragettli, Carenzo, \& McPhee, 2014), it is highly likely that the increase in temperature is causing the headwater glacier in the Elqui catchment to experience melting. This change also affects the snow cover due to the rise of the ZDI (e.g. Demaria et al., 2013). This directly affects surface runoff and aquifer recharge which depends heavily on snow reserves and the process of meltwater infiltration into the soil (and soil frost control).

\section{References}

Azócar, G. F., \& Brenning, A. (2010). Hydrological and geomorphological significance of rock glaciers in the dry Andes, Chile (27-33 S). Permafrost and Periglacial Processes, 21(1), 42-53, DOI: 10.1002 / ppp.669.

Baraer, M., Mark, B. G., McKenzie, J. M., Condom, T., Bury, J., Huh, K. I., Portocarrero, C., Gómez, J., \& Rathay, S. (2012). Glacier recession and water resources in Peru's Cordillera Blanca. Journal of Glaciology, 58(207), 134-150, DOI: 10.3189/2012JoG11J186.

Birsan, M. V., Molnar, P., Burlando, P., \& Pfaundler, M. (2005). Streamflow trends in Switzerland. Journal of Hydrology, 314(1), 312-329, DOI: 10.1016/j.jhydrol.2005.06.008.

Bolch, T. (2007). Climate change and glacier retreat in northern Tien Shan (Kazakhstan/Kyrgyzstan) using remote sensing data. Global and Planetary Change, 56(1), 1-12. DOI: 10.1016/j.gloplacha.2006.07.009.

Cabezas, R., Cepeda, J., \& Bodini, A. (2007). Descripción cartográfica de la hoya hidrográfica del río Elqui. La Serena, Chile: Universidad de la Serena. Consulta hecha el 25 de septiembre de 2016. Recuperado de http://www.parc. $\mathrm{ca} /$ mcri/pdfs/geospatial/cabezas_etal_2008.pdf.

Carrasco, J. F., Osorio, R., \& Casassa, G. (2008). Secular trend of the equilibrium-line altitude on the western side of the southern Andes, derived from radiosonde and surface observations. Journal of Glaciology, 54(186), 538-550, DOI: $10.3189 / 002214308785837002$.

Carrasco, J. F., Casassa, G., \& Quintana, J. (2005). Changes of the $0 \mathrm{C}$ isotherm and the equilibrium line altitude in central Chile during the last quarter of the 20th century/ Changements de l'isotherme $0 \mathrm{C}$ et de la ligne d'équilibre des neiges dans le Chili central durant le dernier quart du 20ème siècle. Hydrological Sciences Journal, 50(6), DOI: 10.1623/hysj.2005.50.6.933.

Demaria, E. M. C., Maurer, E. P., Thrasher, B., Vicuña, S., \& Meza, F. J. (2013). Climate change impacts on an alpine watershed in Chile: Do new model projections change the story? Journal of Hydrology, 502, 128-138, DOI: 10.1016/j. jhydrol.2013.08.027.

DGA (1999). Política nacional de recursos hídricos. Santiago, Chile: Dirección General de Aguas. Consultado el 25 de junio de 2014. Recuperado de http:/ / www.dga.cl/otros / publicacioneslinea/archivos / politicarecursoshidricos. pdf.

Favier, V., Falvey, M., Rabatel, A., Praderio, E., \& López, D. (2009). Interpreting discrepancies between discharge and precipitation in high-altitude area of Chile's Norte Chico region (26-32 S). Water Resources Research, 45(2), DOI: 10.1029/2008WR006802.

Hamed, K. H. (2008). Trend detection in hydrologic data: the Mann-Kendall trend test under the scaling hypothesis. Journal of Hydrology, 349(3), 350-363, DOI: 10.1016/j. jhydrol.2007.11.009. 
Hirose, J. M. R., \& Marshall, S. J. (2013). Glacier Meltwater Contributions and Glaciometeorological Regime of the Illecillewaet River Basin, British Columbia, Canada. Atmosphere-Ocean, 51(4), 416-435, DOI: 10.1080/07055900.2013.791614.

Howat, I. M., Tulaczyk, S., Rhodes, P., Israel, K., \& Snyder, M. (2007). A precipitation-dominated, mid-latitude glacier system: Mount Shasta, California. Climate Dynamics, 28(1), 85-98, DOI: 10.1007/ s00382-006-0178-9.

Jiang, Y., Zhou, C., \& Cheng, W. (2007). Streamflow trends and hydrological response to climatic change in Tarim headwater basin. Journal of Geographical Sciences, 17(1), 5161, DOI: 10.1007 / s11442-007-0051-8.

Karimi, N., Farajzadeh, M., Moridnejad, A., \& Namdari, S. (2014). Evidence for mountain glacier changes in semiarid environments based on remote sensing data. Journal of the Indian Society of Remote Sensing, 42(4), 801-815, DOI: 10.1007/s12524-013-0343-7.

Kendall, M. G. (1948). Rank correlation methods. Oxford, England: Griffin.

Kong, Y., \& Pang, Z. (2014). Statistical analysis of stream discharge in response to climate change for Urumqi River catchment, Tianshan Mountains, central Asia. Quaternary International, 336, 44-51, DOI: 10.1016/j. quaint.2013.05.002.

Le Quesne, C., Acuña, C., Boninsegna, J. A., Rivera, A., \& Barichivich, J. (2009). Long-term glacier variations in the Central Andes of Argentina and Chile, inferred from historical records and tree-ring reconstructed precipitation. Palaeogeography, Palaeoclimatology, Palaeoecology, 281(3), 334-344, DOI: $10.1016 / \mathrm{j}$. palaeo.2008.01.039.

Liu, J., Wang, Z., Gong, T., \& Uygen, T. (2012). Comparative analysis of hydroclimatic changes in glacier-fed rivers in the Tibet-and Bhutan-Himalayas. Quaternary International, 282, 104-112, DOI: 10.1016/j.quaint.2012.06.008.

Mann, H. B. (1945). Nonparametric tests against trend. Econometrica: Journal of the Econometric Society, 245-259, DOI: $10.2307 / 1907187$.

Milana, J. P., \& Güell, A. (2008). Diferencias mecánicas e hídricas del permafrost en glaciares de rocas glacigénicos y criogénicos, obtenidas de datos sísmicos en El Tapado, Chile. Revista de la Asociación Geológica Argentina, 63(3), 310-325.

Milana, J. P., \& Maturano, A. (1999). Application of radio echo sounding at the arid Andes of Argentina: the Agua Negra Glacier. Global and Planetary Change, 22(1), 179-191. DOI: 10.1016/S0921-8181(99)00035-1.

Monnier, S., Kinnard, C., Surazakov, A., \& Bossy, W. (2014). Geomorphology, internal structure, and successive development of a glacier foreland in the semiarid Chilean Andes (Cerro Tapado, upper Elqui Valley, 30 08' S., 69 55' W.). Geomorphology, 207, 126-140, DOI: 10.1016/j. geomorph.2013.10.031.
Oyarzun, C. G. (1987). Inventario de Glaciares de los Andes Chilenos desde los 180 a los 320 de Latitud Sur. Revista de Geografía Norte Grande, 14, 35-48.

Pellicciotti, F., Bauder, A., \& Parola, M. (2010). Effect of glaciers on streamflow trends in the Swiss Alps. Water Resources Research, 46(10), DOI: 10.1029/2009WR009039.

Pellicciotti, F., Ragettli, S., Carenzo, M., \& McPhee, J. (2014). Changes of glaciers in the Andes of Chile and priorities for future work. Science of the Total Environment, 493, 11971210, DOI:10.1016/j.scitotenv.2013.10.055.

Pizarro-Tapia, R., Cabrera-Jofre, C., Morales-Calderón, C., \& Flores-Villanelo, J. P. (2011). Variación temporal de las precipitaciones y caudales en la cuenca del Maipo, y la potencial influencia glaciar en la producción de agua (1963-2006). Tecnología y Ciencias del Agua, 2(3), 5-19.

Pizarro, R., Balocchi, F., Vera, M., Aguilera, A., Morales, C., Valdés, R., Sangüesa, C., Vallejos, C., Fuentes, R., Abarza, A., \& Olivares, C. (2013). Influencia del cambio climático en el comportamiento de los caudales máximos en la zona Mediterránea de Chile. Tecnología y Ciencias del Agua, 4(2), 5-19.

Pourrier, J., Jourde, H., Kinnard, C., Gascoin, S., \& Monnier, S. (2014). Glacier meltwater flow paths and storage in a geomorphologically complex glacial foreland: The case of the Tapado glacier, dry Andes of Chile (30 S). Journal of Hydrology, 519, 1068-1083, DOI: 10.1016/j. jhydrol.2014.08.023.

Rabatel, A., Castebrunet, H., Favier, V., Garrido, R., Herrera, M. J., Marin, J., \& Nicholson, L. (2008). Glacier monitoring in the semi-arid Andes of Chile. Geophysical Research Abstracts, 10:EGU2008-A-00174.

Rabatel, A., Castebrunet, H., Favier, V., Nicholson, L., \& Kinnard, C. (2011). Glacier changes in the Pascua-Lama region, Chilean Andes (29 S): recent mass balance and 50 yr surface area variations. The Cryosphere, 5(4), 1029-1041, DOI: 10.5194/tc-5-1029-2011.

Rignot, E., Rivera, A., \& Casassa, G. (2003). Contribution of the Patagonia Icefields of South America to sea level rise. Science, 302(5644), 434-437, DOI: 10.1126/ science.1087393.

Rivera, A., Acuña, C., Casassa, G., \& Bown, F. (2002). Use of remotely sensed and field data to estimate the contribution of Chilean glaciers to eustatic sealevel rise. Annals of Glaciology, 34(1), 367-372, DOI: 10.3189/172756402781817734.

Rivera, A., Casassa, G., Acuna, C., \& Lange, H. (2000). Variaciones recientes de glaciares en Chile. Investigaciones Geográficas, (34), 26-60.

Sharif, M., Archer, D. R., Fowler, H. J., \& Forsythe, N. (2013). Trends in timing and magnitude of flow in the Upper Indus Basin. Hydrology and Earth System Sciences, 17(4), 1503-1516, DOI: 10.5194/ hess-17-1503-2013.

Singh, P., \& Kumar, N. (1997). Impact assessment of climate change on the hydrological response of a snow and glacier melt runoff dominated Himalayan River. 
Journal of Hydrology, 193(1), 316-350, DOI: 10.1016/S00221694(96)03142-3.

Song, W. Z., Jiang, Y. Z., Lei, X. H., Wang, H., \& Shu, D. C. (2015). Annual runoff and flood regime trend analysis and the relation with reservoirs in the Sanchahe River Basin, China. Quaternary International, 380, 197-206, DOI: 10.1016/j.quaint.2015.01.049.

Souvignet, M., Oyarzún, R., Verbist, K. M., Gaese, H., \& Heinrich, J. (2012). Hydro-meteorological trends in semi-arid north-central Chile (29-32 S): Water resources implications for a fragile Andean region. Hydrological Sciences Journal, 57(3), 479-495, DOI: 10.1080/02626667.2012.665607.

UNESCO (1982). Guía para la elaboración del balance hídrico para América del Sur. Montevideo: Organización de las Naciones Unidas para la Educación, la Ciencia y la Cultura, Chile, Oficina Regional de Ciencia y Tecnología para América Latina y el Caribe, Rostlac.

Valdés-Pineda, R., Pizarro, R., García-Chevesich, P., Valdés, J. B., Olivares, C., Vera, M., Balocchi, F., Pérez, F., Vallejos, C., Fuentes, R., Abarza, A., \& Helwig, B. (2014). Water governance in Chile: Availability, management and climate change. Journal of Hydrology, 519, 2538-2567, DOI: 10.1016/j.jhydrol.2014.04.016.

Vicuña, S., Garreaud, R. D., \& McPhee, J. (2011). Climate change impacts on the hydrology of a snowmelt driven basin in semiarid Chile. Climatic Change, 105(3-4), 469-488, DOI: 10.1007/s10584-010-9888-4.

Wada, T., Chikita, K. A., Kim, Y., \& Kudo, I. (2011). Glacial effects on discharge and sediment load in the Subarctic Tanana river basin, Alaska. Arctic, Antarctic, and Alpine Research, 43(4), 632-648, DOI: 10.1657/1938-4246-43.4.632.

Yamaguchi, S., \& Fujita, K. (2013). Modeling glacier behavior under different precipitation seasonalities. Arctic, Antarctic, and Alpine Research, 45(1), 143-152, DOI: 10.1657/1938-4246-45.1.143.

Yao, Z., Liu, Z., Huang, H., Liu, G., \& Wu, S. (2014). Statistical estimation of the impacts of glaciers and climate change on river runoff in the headwaters of the Yangtze River. Quaternary International, 336, 89-97, DOI: 10.1016/j. quaint.2013.04.026.

Ye, B., Yang, D., Jiao, K., Han, T., Jin, Z., Yang, H., \& Li, Z. (2005). The Urumqi River source glacier No. 1, Tianshan, China: Changes over the past 45 years. Geophysical Research Letters, 32(21), DOI: 10.1029/2005GL024178.
Young, G., Zavala, H., Wandel, J., Smit, B., Salas, S., Jimenez, E., Fiebig, M., Espinoza, R., Diaz, H., \& Cepeda, J. (2010). Vulnerability and adaptation in a dryland community of the Elqui Valley, Chile. Climatic Change, 98(1-2), 245-276, DOI: $10.1007 /$ s10584-009-9665-4.

\section{Author's institutional address}

\section{M.Sc. Francisco Balocchi}

University of Arizona

Department of Hydrology and Water Resources 1133 E. James E. Rogers Way

228, Tucson, AZ 85721, USA

fbalocchi@email.arizona.edu

Instituto Forestal

Av. Sucre 2397

7770223 Santiago, CHILE

Phone: +56 (2) 23667132

Universidad de Talca

Centro Tecnológico de Hidrología Ambiental

Av. Lircay s/n, 3460000 Talca, CHILE

\section{Ph.D. Roberto Pizarro}

Universidad de Talca Centro Tecnológico de Hidrología Ambiental Av. Lircay s/n, 3460000 Talca, CHILE

Phone: +56 (71) 2200375

rpizarro@utalca.cl

Ph.D. Thomas Meixner

University of Arizona

Department of Hydrology and Water Resources 1133 E. James E. Rogers Way

228, Tucson, AZ 85721, USA

Phone: +1 (520) 6261532

tmeixner@email.arizona.edu

\section{B.Sc. Fernando Urbina}

Dirección General de Aguas

Unidad de Hidrología

Tarapacá 130, 1er piso

1100597 Iquique, CHILE

Phone: +56572572265

fernando.urbina@mop.gov.cl 